\title{
PERANAN ASET KOMUNITAS DALAM PENGEMBANGAN MASYARAKAT ISLAM PADA BANK SAMPAH SONGOLIKOER
}

\author{
Wahanani Mawasti \& Fasha Umh Rizky \\ STID AL-HADID SURABAYA \\ wahananimawasti@yahoo.co.id \& rizfast6@yahoo.com
}

\begin{abstract}
Abstrak: Pengembangan masyarakat Islam merupakan salah satu bentuk dakwah bil hal melalui upaya membangun keinginan dan partisipasi masyarakat untuk memperbaiki kondisi yang ada. Salah satunya dengan pengembangan masyarakat lokal yang bersifat bottom-up, yang mensyaratkan peranan aset komunitas untuk menjamin keberlangsungan dan keberhasilan kegiatan pengembangan masyarakat dalam meningkatkan kesejahteraan masyarakat. Salah satu upaya pengembangan masyarakat adalah meningkatkan kesejahteraan ekonomi melalui bank sampah. Tulisan ini, mendeskripsikan peranan aset komunitas dalam konteks pengembangan masyarakat Islam, melalui bank sampah. Sejauh ini studi terdahulu tentang peranan aset lebih menguraikan tentang peranan aset sosial dalam pengentasan kemiskinan, namun tidak cukup banyak membahas peranan jenis aset komunitas yang selainnya. Metode penelitian yang digunakan adalah kualitatif deskriptif dengan teknik wawancara semi terstruktur dan observasi. Dari studi ini menunjukkan bahwa masing-masing aset memiliki peranan yang berbeda-beda dalam proses pengembangan masyarakat. Aset yang sangat berperan dalam pengembangan Bank Sampah Songolikoer adalah aset manusia, social, dan spiritual. Peranan berbagai aset komunitas pada Bank Sampah Songolikoer membawa dampak positif pada peningkatan kesejahteraan masyarakat, baik aspek ekonomi, lingkungan, sosial, dan budaya.

Kata kunci: pengembangan masyarakat Islam, peranan aset komunitas, bank sampah
\end{abstract}

\begin{abstract}
Community development is one form of propagation by deeds through encouraging communal desire and participation in order to improve existing conditions. Empowerment or bottom-up approach of community development requires the role of community assets to ensure the sustainability and its success in improving community welfare. One of the efforts to empower community is by improving economic welfare through waste bank. This discourse describes about the role of community assets for empowering Islamic community through the waste bank. So far, the research on the role of community assets elaborates more on alleviating poverty, but does not discuss about the other communication assets. This study uses descriptive qualitative method with semi-structured interview techniques and observation. The result shows that each asset has a different role in the process of empowerment. Assets playing an essential role in developing Waste Bank of Songolikoer are human, social and spiritual assets. The role of various community assets in Waste Bank of Songolikoer has a positive impact in improving people's welfare, such as economic, environmental, social and cultural aspects.
\end{abstract}

Keywords: Islamic community development, role of community assets, waste bank 


\section{Pendahuluan}

Tulisan ini membahas peranan aset komunitas dalam kegiatan pengembangan masyarakat Islam yang dilaksanakan oleh Bank Sampah Songolikoer. Pengembangan masyarakat Islam adalah upaya menggerakkan keinginan dan partisipasi aktif masyarakat dalam melakukan perbaikan terhadap kondisi masyarakat. ${ }^{1}$ Tujuannya agar masyarakat mampu secara mandiri memecahkan permasalahan dan memenuhi kebutuhan hidupnya. ${ }^{2}$ Pengembangan masyarakat merupakan perwujudan tanggung jawab dakwah bilhal, dalam rangka memenuhi fitrah manusia, baik jasmani maupun rohani, berlandaskan nilai universal Islam meliputi: keadilan, kerja sama, pemerataan, musyawarah, ekonomis, dan dikelola dengan prinsip efektif dan akuntabel. ${ }^{3}$

Dalam pengembangan masyarakat Islam, agar dapat terus berjalan dan memiliki efek jangka panjang, hendaknya perlu memanfaatkan sumber daya lokal/aset komunitas di masyarakat, agar memunculkan kemandirian masyarakat dan tidak bergantung dengan pihak luar dalam jangka panjangnya. ${ }^{4}$ Pengembangan masyarakat berbasis aset komunitas, dimulai dari memetakan sumber daya yang

\footnotetext{
${ }^{1}$ Faizal, "Dakwah Bil Hal Dalam Perspektif Al-Qur'an," Jurnal Ilmu Dakwah dan Pengembangan Komunitas, vol. 8, no. 2 (Juli 2013): 6.

2 Isbandi Rukmianto Adi, Intervensi Komunitas \& Pengembangan Masyarakat Sebagai Upaya Pemberdayaan Masyarakat, (Jakarta: PT Raja Grafindo Persada, 2013), 205.

3 Kamaluddin, "Dakwah dan Pengembangan Masyarakat Islam (Konsep Dasar dan Arah Pengembangan)," HIKMAH: Jurnal Dakwah dan Komunikasi Islam, vol. 8, no.2 (2004): 51.

4 Isbandi Rukmianto Adi, Intervensi Komunitas \& Pengembangan Masyarakat Sebagai Upaya Pemberdayaan Masyarakat (Jakarta: PT Raja Grafindo Persada, 2013), 87-98.
}

ada di suatu komunitas. Hal ini berguna untuk mengetahui kapasitas, kekuatan, dan aset yang ada dalam komunitas sehingga dapat dikembangkan secara lebih optimal. $^{5}$

David Cooperrider (dikutip oleh Christopher Dureau) melakukan studi tentang bagaimana organisasi berkembang, berpendapat bahwa pendekatan pemecahan masalah tidak efektif untuk membawa perubahan dibandingkan pendekatan yang lebih dahulu memperhatikan apa yang bisa menghidupkan (aset komunitas) suatu organisasi. Cooperrider menemukan bahwa ketika orang melihat kembali sejarah mereka, memperhatikan capaian terbaik yang pernah diraih dan menemukan sumber inspirasi, kekuatan dan kepentingan mereka, lalu menggunakan pengetahuan tersebut sebagai basis untuk bergerak maju, maka mereka menjadi lebih mampu dan berkomitmen untuk mencapai perubahan yang mereka inginkan. ${ }^{6}$ Menurut Dureau, aset komunitas adalah sesuatu yang berharga yang bisa digunakan untuk meningkatkan harkat/kesejahteraan. ${ }^{7}$ Hal ini menunjukkan kekuataan aset komunitas memiliki peranan penting dalam upaya pengembangan masyarakat. Khususnya, pendekatan pengembangan masyarakat lokal yang bernuansa buttom-up dan

\footnotetext{
${ }^{5}$ Abdillah Ubaidi Djawahir, "Asset Based Community Development di Pesantren Wisata: Implementasi Strategis di PP An-Nur 2 Al Murtadlo Malang," AtTamkin: Jurnal Pengabdian Kepada Masyarakat, vol 1, no. 1 (Juni 2018), 24.

${ }^{6}$ Christopher Dureau, Pembaru dan Kekuatan Lokal Untuk Pembangunan, (Australian Community Development and Civil Society Strengthening Scheme Tahap II, 2013), 10-11.

7 Ibid., 145.
} 
berorientasi pada kemandirian dan keterlibatan masyarakat. $^{8}$

Peranan aset komunitas dalam meningkatkan kesejahteraan masyarakat amatlah penting, khususnya pada pengembangan masyarakat miskin. Robert Cambers (dikutip oleh Jaeni Dahlan) menyatakan bahwa setiap masyarakat, termasuk masyarakat miskin, sejatinya memiliki kapasitas atau aset-aset yang dapat menjadi sarana menolong diri mereka sendiri. ${ }^{9}$ Hal ini sebagaimana pengembangan masyarakat yang dilaksanakan oleh Bank Sampah Songolikoer. Bank Sampah Songolikoer memanfaatkan aset-aset yang terdapat di masyarakat untuk dapat meningkatkan kesejahteraan masyarakat.

Bank Sampah Songolikoer berdiri di wilayah Wonokusumo Kidul, Surabaya. Masyarakat di wilayah ini cukup banyak yang miskin, ${ }^{10}$ serta memiliki persoalan di bidang kepedulian terhadap lingkungan dan sosial. Sejauh ini, semua nasabah Bank Sampah Songolikoer seluruhnya merupakan muslim. Masyarakat Wonokusumo Kidul, mayoritasnya merupakan masyarakat muslim ${ }^{11}$ yang gemar menghidupkan berbagai kegiatan keagamaan. Misalnya, pengajian, yasin dan

8 Edi Soeharto, Membangun Masyarakat Memberdayakan Rakyat (Kajian Strategis Pembangunan Kesejahteraan Sosial dan Pekerjaan Sosial), (Bandung: Ikapi, 2014), 43-44.

9 Jaeni Dahlan, "Pemanfaatan Aset Komunitas Melalui Pendekatan Appreciative Inquiry Dalam Penanggulangan Kemiskinan di Kabupaten Bandung Barat," Jurnal Ilmiah Pekerjaan Sosial, vol. 15, no. 2 (Desember 2016) 275.

10 Tri Djoyo Budiono (penggagas Bank Sampah Songolikoer, penggerak remaja masjid untuk aktif pada kader lingkungan), wawancara oleh Wahanani, tanggal 13 April 2018.

11 Ibid. tahlil, kegiatan salat berjemaah, kegiatan tadarus saat bulan suci Ramadan, kegiatan peringatan hari besar Islam, kesenian Islam (rebana), budaya masyarakat Islam (megengan dan nyadran). ${ }^{12}$ Bank Sampah Songolikoer lahir dalam rangka meningkatkan kepedulian masyarakat Islam terhadap lingkungan dan meningkatkan kesejahteraan ekonomi masyarakat. Bank sampah ini dikembangkan oleh Komunitas Kader Lingkungan Wonokusumo Kidul ${ }^{13}$ bersama dengan intervensi komunitas dari salah satu perguruan tinggi Islam swasta di Surabaya mulai tahun 2018. Bank sampah ini memiliki semangat "Ngresiki kampung lillāhi ta'āla" yang memiliki arti membersihkan kampung dengan nilai lillāhi ta'āla.

Hal itu dimulai dari anggota Remaja Masjid Wonokusumo Kidul yang memiliki keinginan untuk menjadi orang baik yang bisa memberikan manfaat bagi agama dan masyarakat. Mereka memiliki pandangan, meskipun tidak memiliki cukup harta, tapi mereka memiliki tenaga untuk memperbaiki lingkungan sekitar sebagai amal saleh dan bentuk ibadah kepada Allah Swt. ${ }^{14}$ Potensi inilah yang digunakan sebagai titik awal membuat Bank Sampah Songolikoer.

Dalam upaya pengembangan masyarakat Islam dalam bentuk Bank Sampah Songolikoer, menggunakan metode bottom

12 Kegiatan membuat apem dan mengunjungi makam sebelum menyambut bulan suci Ramadan.

13 Kader Lingkungan Wonokusumo Kidul, memiliki anggota yang berasal dari anak-anak remaja masjid Ar-Rahman Surabaya serta ibu-ibu Kader Posyandu Wonokusumo Kidul Surabaya.

14 Tri Djoyo Budiono, wawancara, tanggal 13 April 2018. 
up dan model pengembangan masyakat lokal, yaitu dengan mengoptimalkan asetaset komunitas seperti: budaya lokal, solidaritas, partisipasi aktif masyarakat, nilai-nilai spiritual serta potensi alam berupa sampah yang berlimpah untuk dapat menjadikan masyarakat menjadi lebih berdaya. Aset spiritual, terkait dengan nilai-nilai keislaman masyarakat menjadi salah satu aset penting dalam pengembangan Bank Sampah Songolikoer. Dengan kesadaran adanya aset komunitas yang dimiliki masyarakat, melahirkan optimisme baru bahwa masyarakat Wonokusumo Kidul dapat berubah lebih baik. $^{15}$

Pengembangan masyarakat yang dilaksanakan oleh Bank Sampah Songolikoer tergolong berhasil dalam membantu meningkatkan kesejahteraan masyarakat. Kesejahteraan masyarakat bisa meliputi pemenuhan kebutuhan material/ekonomi, spiritual, dan sosial agar dapat hidup lebih layak dan mampu mengembangkan diri. ${ }^{16}$

Pertama, adanya bank sampah dapat meningkatkan pendapatan ekonomi masyarakat. Dalam satu semester, bank sampah dapat mengumpulkan $\mathrm{Rp}$ 10.000.000,00. ${ }^{17}$ untuk dibagikan pada masing-masing nasabah sesuai dengan kontribusinya dalam mengumpulkan sampah. Masyarakat, khususnya ibu-ibu dan remaja sangat antusias

15 Ibid.

16 Pasal 1 Undang-undang Republik Indonesia Nomor 11 Tahun 2009 Tentang Kesejahteraan Sosial. https://luk.staff.ugm.ac.id/atur/sehat/UU-112009KesejahteraanSosial.pdf

17 Siti Romlah (Ketua Bank Sampah Songolikoer), wawancara oleh Wahanani, tanggal 11 Desember 2019. mengumpulkan sampah guna menjaga lingkungan sekaligus mendapatkan tambahan pemasukan ekonomi. Pemasukan dari mengumpulkan sampah tersebut ditabung di Bank Sampah, kemudian dibagikan tiap bulan Ramadan untuk memenuhi kebutuhan hari raya. Masyarakat juga bisa mengambil tabungan sampah pada waktu tertentu apabila membutuhkan untuk biaya hidup maupun sekolah yang dipandang mendesak. ${ }^{18}$

Kedua, meningkatnya kesadaran masyarakat terhadap lingkungan. Jika dulu masyarakat sangat acuh terhadap lingkungan, setelah adanya bank sampah masyarakat berlomba-lomba untuk mengumpulkan sampah dan membersihkan lingkungan. Jika ada hajatan, saat ini sangat jarang ada sampah kering/plastik tersisa, semua orang berebut untuk mengumpulkan sampah. Sampah dalam bentuk minyak bekas (jelantah) juga tak luput menjadi perhatian masyarakat. Masyarakat tidak lagi membuang minyak bekas penggorengan ke selokan, karena minyak tersebut memiliki nilai jual yang tinggi di Bank Sampah. ${ }^{19}$ "Program lingkungan sebelumnya tidak jalan karena kesadaran warga rendah, contoh; dikasih tong sampah gak jalan, dikasih pot banyak yang rusak, dikasih tanaman juga banyak yang mati. Banyaknya program lingkungan yang hanya semarak saat ada lomba green and clean, setelah itu tidak semarak lagi, sebab tidak adanya program yang berkesinambungan. Namun, setelah adanya bank sampah masyarakat mulai sadar untuk mengumpulkan sampah bahkan ketika ada hajatan warga banyak

\footnotetext{
18 lbid.

19 Harga minyak bekas penggorengan, 1 1/2 liternya adalah Rp. 9000.
} 
masyarakat yang berlomba-lomba untuk mengumpulkan sampah. Mengingat dengan sampah yang dikumpulkan bisa memberikan tambahan pemasukan ekonomi”20

Ketiga, meningkatnya jumlah nasabah yang berpartisipasi aktif dalam Bank Sampah. Jika awal pendirian, jumlah nasabah hanya 15 orang, saat ini telah mencapai 60 orang lebih. Keberhasilan Bank Sampah Songolikoer, tidak dapat dilepaskan dari adanya aset-aset komunitas yang terus digali dan dimanfaatkan agar kegiatan bank sampah dapat terus berlanjut, berkembang hingga dapat membawa manfaat-manfaat bagi masyarakat. Tanpa adanya aset komunitas yang dimanfaatkan maka akan mustahil masyarakat dapat termotivasi serta mampu mandiri dalam melaksanakan kegiatan pengembangan masyarakat.

Masing-masing jenis aset komunitas yang terdapat di Bank Sampah Songolikoer, memiliki karakteristik dan peranan yang berbeda dalam pelaksanaan kegiatan pengembangan masyarakat. Dengan mengetahui masing-masing jenis dan peranan aset komunitas, dapat makin mengoptimalkan aset komunitas yang ada untuk kegiatan pengembangan masyarakat sejenis. Oleh karena itu, studi ini bertujuan menguraikan bentuk, karakteristik dan peranan masing-masing jenis aset komunitas dalam kegiatan pengembangan masyarakat Islam, khususnya dalam tahapan pelaksanaan Bank Sampah.

20 Agus Winarto (Ketua RW 2018-2019, penggagas Bank Sampah Songolikoer, dan pembina kader lingkungan), wawancara oleh Wahanani, tanggal 17 April 2018.
Dari penelusuran studi terdahulu, terdapat beberapa kajian yang membahas tentang aset komunitas dalam pengembangan masyarakat antara lain: 1) studi yang dilaksanakan oleh Fedryansyah dan Resnawaty, ${ }^{21}$ menghasilkan kesimpulan jenis-jenis aset yang memungkinkan dikembangkan di Kecamatan Jatinangor, meliputi aset fisik, sumber daya manusia, dan aset sosial. Serta menghasilkan saran bagi pemerintah Kabupaten Sumedang untuk memanfaatkan ketiga aset tersebut untuk merancang program pembangunan 2) jurnal yang ditulis oleh Dahlan, ${ }^{22}$ menghasilkan gambaran tahapan pemanfaatan aset komunitas melalui teknik appreciative inquiry, dan pengembangan desain pemanfaatan aset komunitas di Desa Cihampelas. Sekaligus mengonfirmasi teori dari Green dan Haines mengenai peran penting sumber daya manusia (aset manusia dan aset sosial) dalam mengembangkan aset selainnya. Pada kedua studi di atas, membahas aset komunitas dengan tujuan memberikan rekomendasi desain program pengembangan masyarakat berbasis aset komunitas dengan menggunakan metode action research. Hal ini berbeda dengan studi ini yang menguraikan peranan aset komunitas dalam pengembangan masyarakat Islam berdasarkan fenomena yang telah dilaksanakan dan berhasil dilakukan oleh Bank Sampah Songolikoer. Studi terdahulu juga lebih memfokuskan pada tahapan pengembangan masyarakat

21 Muhammad Fedryansyah dan Risna Resnawaty, "Penanggulangan Kemiskinan Melalui Pengembangan Aset Komunitas," Social Work Journal, vol. 7, no. 1 (Juli 2017): 124.

22 Jaeni Dahlan, "Pemanfaatan Aset Komunitas Melalui Pendekatan Appreciative Inquiry Dalam Penanggulangan Kemiskinan di Kabupaten Bandung Barat," Jurnal IImiah Pekerjaan Sosial, vol. 15, no. 2 (Desember 2016): 275. 
berbasis aset komunitas, dibandingkan menguraikan masing-masing peranan aset komunitas dalam pemberdayaan masyarakat.

Adapun studi terdahulu yang membahas tentang peranan aset komunitas adalah: studi dari Cahyono ${ }^{23}$ menggunakan teori modal sosial yang terkait dengan bagaimana hubungan yang tercipta dan norma-norma dalam masyarakat dapat dimanfaatkan dalam kegiatan pengembangan masyarakat. Hasil studi menunjukkan cara-cara untuk meningkatkan optimalisasi modal sosial pada masyarakat petani di Kabupaten Wonosobo seperti memberikan pembinaan sesuai kebutuhan, melakukan bimbingan pemasaran hasil produksi, pelatihan teknis bertani yang efektif. Studi lainnya dari Nasution ${ }^{24}$ yang menggunakan metode kuantitatif dengan analisis regresi linier berganda, mengukur pengaruh modal sosial terhadap kemiskinan rumah tangga di pedesaan di Indonesia. Hasilnya menunjukkan bahwa modal sosial bersama-sama dengan modal manusia, finansial, dan fisik, dapat memberikan efek positif terhadap pengeluaran per kapita rumah tangga, sehingga dapat mengurangi kemiskinan. Dari kedua studi tersebut, lebih menguraikan peranan aset komunitas, spesifiknya pada jenis aset sosial pada persoalan kemiskinan. Sedangkan, modal-modal yang selainnya

23 Budhi Cahyono dan Ardian Adhiatma, "Peran Modal Sosial Dalam Peningkatan Kesejahteraan Masyarakat Petani Tembakau di Kabupaten Wonosobo." Proceedings of Conference in Business, Accounting and Management (CBAM) vol. 1, no. 1 (Desember 2012): 131-144.

${ }^{24}$ Ahmadriswan Nasution, "Peranan Modal Sosial dalam Pengurangan Kemiskinan Rumah Tangga di Pedesaan Indonesia," Jurnal Ekonomi \& Kebijakan Publik, vol. 7, no. 2 (Desember 2016): 171-183. seperti: modal spiritual, institusi, fisik, dan lain sebagainya tidak banyak dibahas peranannya dalam pengembangan masyarakat. Selain itu, pada studi terdahulu aspek peranan yang diungkap dikaitkan dengan pemecahan persoalan kemiskinan secara umum, sedangkan tulisan ini hendak mengurai peranan masing-masing jenis aset pada proses pengembangan masyarakat Islam dalam bentuk Bank Sampah.

Pengembangan masyarakat melalui Bank Sampah, saat ini banyak dikembangkan pada masyarakat perkotaan untuk mengatasi persoalan kesejahteraan dan lingkungan. Menurut Kementerian Lingkungan Hidup saat ini sudah ada 1195 bank sampah yang tersebar di 55 kota di Indonesia ${ }^{25}$. Beberapa di antaranya ada yang berhasil namun juga ada yang mengalami kegagalan. Kegagalan tersebut salah satunya, disebabkan oleh tidak adanya kesadaran terhadap potensi aset komunitas yang ada di masyarakat. Sehingga, masyarakat tidak dapat mengoptimalkan aset yang dimiliki untuk melakukan pengembangan masyarakat yang sesuai dengan potensi aset. Pengembangan masyarakat yang dikembangkan selama ini lebih berfokus pada masalah dibandingkan dengan aset yang dimiliki, sehingga justru yang terjadi adalah pesimistis. Tanpa pemahaman tentang peranan aset komunitas, akan mengalami kesulitan dalam merumuskan pemecahan masalah masyarakat. Untuk itu, menjadi penting untuk menguraikan aset-aset komunitas dan peranannya khususnya dalam pengembangan Bank

\footnotetext{
25 Unilever Indonesia, Buku Panduan Sistem Bank Sampah \& 10 Kisah Sukses (Jakarta: Unilever, 2014), 2.
} 
Sampah. Sehingga, dapat menjadi inspirasi bagi bank sampah lainnya untuk mengoptimalkan aset-aset komunitas yang dimiliki dalam rangka meningkatkan kualitas hidup masyarakat di bidang ekonomi, kesehatan, dan lingkungan.

Studi ini menggunakan field research menggunakan observasi dan wawancara semi terstruktur. Informan ditetapkan secara purposive, berdasarkan kriteria pihak-pihak yang dipandang mengetahui terkait aset komunitas yang terdapat di wilayah Wonokusumo Kidul serta peranannya selama ini dalam pendirian Bank Sampah Songolikoer. Informan dalam studi ini antara lain: Ketua Bank Sampah Songlikoer (Ibu Romlah); Ketua RW Wonokusumo Kidul tahun 2018-2019, yang juga salah satu penggagas Bank Sampah Songolikoer (Bapak Agus W); Penggagas Bank Sampah Wonokusumo Kidul (Bapak Tri Djoyo Budiono); Ketua Kader Lingkungan Wonokusumo Kidul (Sdr. Rudi). Informasi yang diperoleh tersebut akan dipelajari dan ditafsirkan dengan usaha memaknai sesuai dengan sudut pandang sumber data. ${ }^{26}$ Periset dalam penelitian ini adalah bagian integral dari data, yang secara aktif menjadi instrumen untuk terjun ke lapangan secara mendalam. ${ }^{27}$

Data yang telah dihimpun kemudian dianalisis dengan metode analisis interaktif dari Miles dan Huberman yaitu reduksi data, penyajian data, dan penarikan kesimpulan serta verifikasi dengan teknik

${ }^{26}$ Hadri Nawawi dan M. Matini Nawawi, Instrumen Penelitian Bidang Sosial, (Yogyakata : Gajah Mada University Press, 1992), 209.

27 Rachmat Kriyantono, Teknik Praktis Riset Komunikasi: Disertai Contoh Praktis Riset Media, Public Relation, Advertising, Komunikasi Organisasi, Komunikasi Pemasaran, (Jakarta: Kencana, 2010), 57. triangulasi sumber. ${ }^{28}$ Penggunaan metode itu sesuai dengan konteks penelitian ini yang menggunakan data-data kualitatif, baik dari literatur, observasi maupun hasil wawancara. Data-data tersebut butuh direduksi untuk karakteristik masingmasing aset dan menemukan hubungan aset dalam pelaksanaan masing-masing tahap pengembangan Bank Sampah.

\section{Pengembangan Masyarakat Islam Melalui Bank Sampah}

Dunham dalam Isbandi menjelaskan, "Pengembangan masyarakat sebagai upaya-upaya terorganisir untuk meningkatkan kehidupan masyarakat, terutama melalui usaha yang kooperatif dan mengembangkan kemandirian dari masyarakat. Hal itu dapat dilakukan dengan bantuan teknis dari pemerintah ataupaun lembaga sukarela." ${ }^{29}$ Pengembangan masyarakat ditujukan untuk meningkatkan kemampuan dan kemandirian masyarakat memenuhi kebutuhan hidupnya. Dengan adanya kegiatan pengembangan masyarakat, harapannya dapat memberi kekuatan pada mereka yang lemah dan dirugikan. ${ }^{30}$ Kegiatan pengembangan masyarakat berangkat dari adanya permasalahan di masyarakat, seperti: kemiskinan, diskriminasi, ketimpangan, persoalan lingkungan, dan lain sebagainya.

Kegiatan pengembangan masyarakat melalui bank sampah merupakan upaya

\footnotetext{
28 Ibid., 246.

${ }^{29}$ Adi, Intervensi Komunitas, 160.

30 Jim Ife dan Frank Tesoriero, Community Development: Alternatif Pengembangan Masyarakat Di Era Globalisasi, (Yogyakarta: Pustaka Pelajar, 2016), 130.
} 
untuk meningkatkan kapasitas masyarakat agar dapat meningkatkan kesejahteraannya, baik secara ekonomi, sosial, maupun lingkungan yang sehat. Pendirian dan pengembangan bank sampah memiliki beberapa proses yang harus dilalui antara lain: ${ }^{31}$ pertama, sosialisasi awal yaitu memberikan pengetahuan dasar dan pengenalan bank sampah kepada masyarakat. Pengenalan dapat berbagai aspek terkait sistem bank sampah. Sosialisasi awal ini harus mampu menonjolkan berbagai aspek positif dari kegiatan bank sampah sehingga masyarakat mau untuk bergerak bersama melaksanakan sistem bank sampah.

Kedua, pelatihan teknis. Pelatihan teknis ini meliputi pelatihan pengurus maupun masyarakat terhadap sistem yang akan diterapkan oleh bank sampah. Tujuannya agar calon nasabah dan pengurus memahami standarisasi sistem bank sampah, mekanisme kerja, dan keuntungan bank sampah. Sehingga, masyarakat menjadi siap untuk melaksanakan pemilahan dan penyetoran sampah ke bank sampah. Ketiga, pelaksanaan sistem bank sampah. Proses pelaksanaan bank sampah dilakukan pada hari-hari tertentu yang telah disepakati. Perlu adanya pengurus yang siap dalam keperluan administrasi, melaksanakan penimbangan dan pemilahan lagi apabila ada sampah-sampah yang belum terpilah. Idealnya, nasabah datang ke bank sampah dengan membawa sampah yang sudah dipilah, kemudian mendapatkan uang yang disimpan dalam bentuk tabungan sesuai dengan nilai sampah yang disetor.

31 Unilever Indonesia, Buku Panduan Sistem Bank Sampah \& 10 Kisah Sukses, 8-9.
Keempat, pemantauan dan evaluasi. Berbagai tantangan mungkin muncul dalam pelaksanaan bank sampah. Oleh karena itu perlu untuk senantiasa dilakukan proses pemantauan dan evaluasi untuk memecahkan masalah masyarakat lebih cepat. Evaluasi dilakukan agar proses pelaksanaan bank sampah menjadi lebih baik. Kelima, tahap pengembangan. Sistem bank sampah memungkinkan berkembang menjadi berbagai unit lainnya, misalnya: unit sembako, unit simpan pinjam, dan lain sebagainya. Bahkan dimungkinkan menjadi badan hukum seperti koperasi.

\section{Aset Komunitas}

Menurut Dureau, kata aset secara sengaja digunakan untuk meningkatkan kesadaran komunitas yang sudah 'kaya dengan aset' atau memiliki kekuatan yang dapat digunakan sekarang dan secara lebih baik lagi. ${ }^{32}$ Menurut John L. McKnight \& Cormac Russell, aset lokal adalah sumber daya yang digunakan untuk meningkatkan kesejahteraan lokal. Aset ini berlimpah (jumlah yang cukup untuk semua orang dan ketika dibagikan secara produktif tidak habis). Setiap komunitas pasti memiliki aset dan berguna bagi komunitas yang ingin menyelesaikan masalah untuk meningkatkan kesejahteraan komunitas. ${ }^{33}$

Menurut Isbandi ada beberapa jenis aset komunitas antara lain: aset manusia, aset fisik, aset finansial, aset teknologi, aset lingkungan, aset sosial, dan aset spiritual. ${ }^{34}$

\footnotetext{
32 Dureau, Pembaru dan Kekuatan Lokal, 145.

33 John McKnight \& Cormac Russel, The Four Essential Elements of an Asset-Based Community Development Process, (Asset-Based Community Development Institute, 2018), 3.

${ }^{34} \mathrm{Adi}$, Intervensi Komunitas, 239.
} 
Penjelasan terkait masing-masing aset

komunitas berdasarkan konsep yang dikemukakan oleh Isbandi Rukminto $\mathrm{Adi}^{35}$, Christopher Dureau ${ }^{36}$ dan Aprilia Theresia ${ }^{37}$ ditunjukkan pada bagan berikut ini:
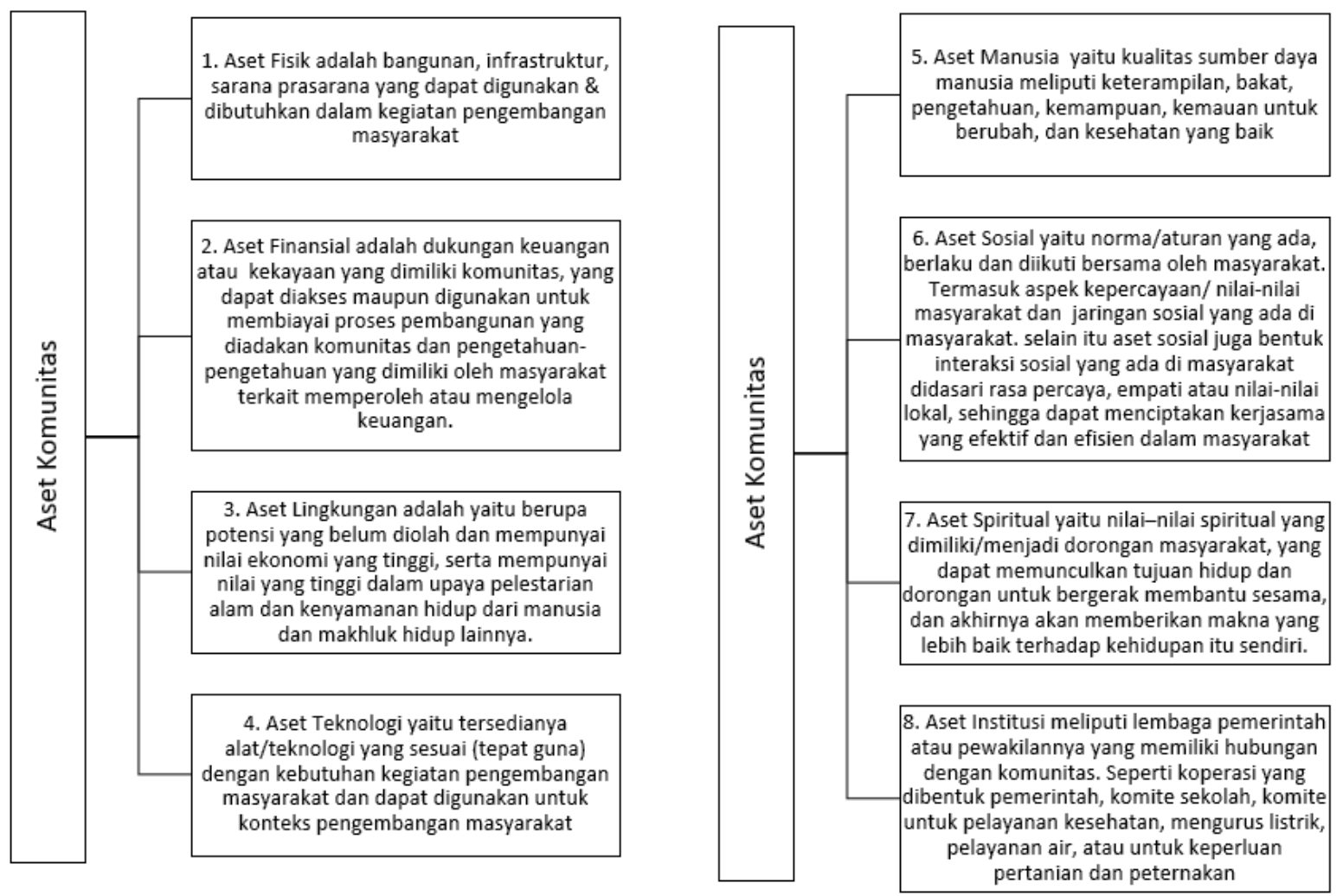

Bagan 1 - Ragam Jenis Aset Komunitas

\section{Peranan Aset Komunitas Dalam Pengembangan Masyarakat Islam Melalui Bank Sampah}

Aset komunitas memiliki peranan penting dalam kegiatan pengembangan masyarakat. Hal itu dikarenakan dengan adanya pemahaman dan pengenalan terhadap potensi aset komunitas yang dimiliki membuat masyarakat terus bisa mandiri, berdaya, dan mengembangkan komunitasnya sendiri. Sekalipun sudah tidak ada intervensi pihak luar.

35 Ibid., 239-263.

${ }^{36}$ Dureau, Pembaru dan Kekuatan Lokal, 147-148.

37 Aprilia Theresia, Pembangunan Berbasis Masyarakat, (Bandung: Alfabeta, 2015), 36.
Oleh karena itu, dalam pendekatan pengembangan masyarakat lokal, aset komunitas berperan penting untuk menjamin keberlangsungan kegiatan pengembangan masyarakat.

Peranan juga bisa diistilahkan dengan fungsi, yaitu kegunaan suatu hal, ${ }^{38}$ dalam hal ini berarti kegunaan aset-aset komunitas dalam program pengembangan masyarakat. Misalnya, peran modal spiritual dalam proses pembangunan sosial, pengembangan masyarakat meliputi beberapa fungsi, antara lain untuk: 1)

38 Kamus Besar Bahasa Indonesia, aplikasi android, 1.5 keyword: fungsi 
meningkatkan etos kerja dan memberikan daya dorong atau semangat yang positif dalam melakukan pembangunan; 2) memberikan jiwa dalam upaya pemberian bantuan; 3) memberikan arah dalam pembangunan; dan 4) menjadi pelindung terhadap penyimpangan. ${ }^{39}$

Peranan aset komunitas adalah terkait dengan kedudukan dan fungsi aset komunitas tersebut dalam implementasi kegiatan pembangunan/pengembangan masyarakat. Misalnya: 1) aset lingkungan dapat difungsikan sebagai produk daya tarik pada pengembangan masyarakat melalui desa wisata, memiliki nilai tinggi dalam upaya menjaga kelangsungan (kelestarian) alam, dan menunjang kenyamanan hidup masyarakat dalam melakukan kegiatan pengembangan masyarakat; 2 ) aset fisik dapat difungsikan sebagai indikator keberhasilan pengembangan komunitas, sumber daya pendukung keberhasilan pelaksanaan kegiatan pengembangan masyarakat, dan lain sebagainya; 3) aset dana difungsikan untuk membiayai berbagai kebutuhan pelaksanaan kegiatan pengembangan masyarakat.

Peranan aset komunitas dapat ditemukan dalam pelaksanaan tahapan pengembangan masyarakat dalam bentuk bank sampah, mulai dari proses sosialisasi awal, transformasi kemampuan atau pelatihan teknis, proses pelaksanaan kegiatan bank sampah, hingga proses evaluasi hasil perubahan, pengembangan program-program bank sampah selanjutnya hingga dapat meningkatkan kesejahteraan masyarakat.

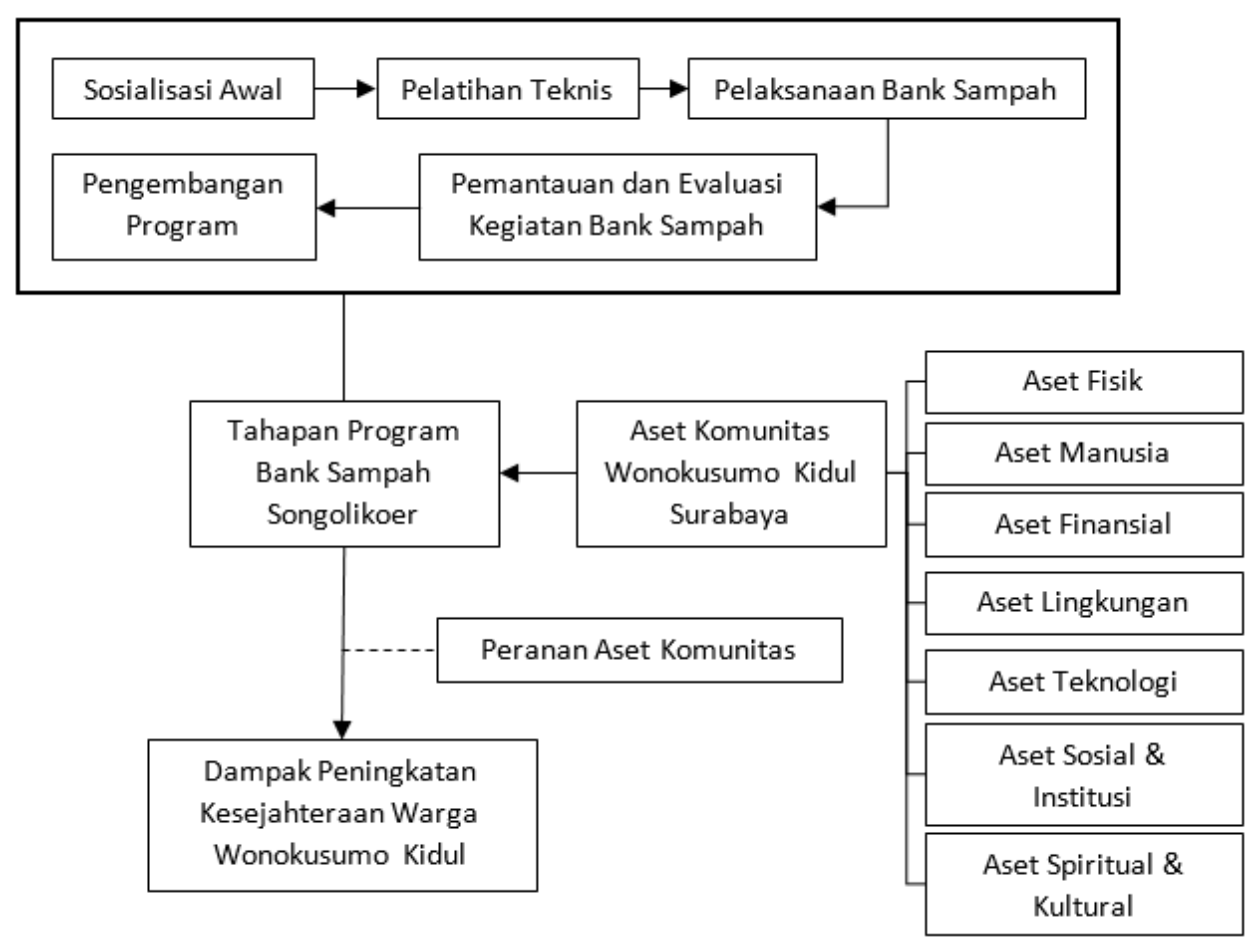

Bagan 2 - Kerangka Berpikir Peranan Aset Komunitas Dalam Pengembangan Bank Sampah

\footnotetext{
${ }^{39}$ Adi, Intervensi Komunitas, 264.
} 


\section{Bank Sampah Songolikoer}

Bank Sampah Songolikoer digagas olah Kader Lingkungan Wonokusumo Kidul pada tahun 2018, serta mulai resmi berdiri dan beroperasi pada bulan Januari tahun 2019 . Pada tahap awal sebelum beroperasi, para penggagas bank sampah yang terdiri dari Ketua RW (Bapak Agus), Pembina Remaja Masjid (Bapak Tri Djoyo), Ketua Kader Lingkungan (Rudianto) didampingi oleh beberapa dosen dari perguruan tinggi Islam di Surabaya, melakukan proses Assesment potensi aset komunitas di wilayah Wonokusumo Kidul serta merancang program Bank Sampah. Proses selanjutnya adalah pelatihan kemampuan SDM serta sosialisasi awal kepada masyarakat calon nasabah Bank Sampah. Setelah adanya pengurus yang terampil, infrastruktur dan kesadaran nasabah, barulah kegiatan bank sampah dilaksanakan secara rutin tiap hari Rabu dan Jumat malam, di depan balai RW 06 kampung Wonokusumo Kidul. Bank sampah ini dinamai dengan Bank Sampah Songolikoer, mengingat sebagian besar warga yang menjadi nasabahnya saat itu tinggal di rumah yang nomornya 29.

Pada awal pendirian, bank sampah ini masih berfokus pada menjalankan sistem bank sampah sebagaimana umumnya yaitu mengumpulkan, memilah dan menimbang sampah. Setelah satu tahun berdiri, tepatnya bulan Januari 2020. Bank sampah mulai memiliki beberapa program pengembangan seperti simpan pinjam bayar sampah dan membuat serta menjual berbagai hasil kerajinan tangan nasabah Bank Sampah Songolikoer. Selain itu, saat ini Bank Sampah Songolikoer mulai merancang upaya kerja sama dengan perusahaan untuk mendapatkan bantuan dana CSR dalam rangka pengembangan program-program bank sampah ke depannya.

Bank Sampah Songolikoer merupakan bank sampah yang didirikan di RW 06 pada wilayah Wonokusumo Kidul. Masyarakat RW 06 Wonokusumo Kidul terdiri dari empat RT, dengan karakteristik sosial ekonomi masyarakat yang berbeda. Masyarakat RT 2 dan RT 3, kebanyakan merupakan pekerja di sektor informal yang terdiri dari tukang becak, buruh pasar, pegawai toko, pekerja di percetakan kitab, tukang sampah, dan penggali kubur. Sedangkan, RT 01 dan RT 04, kebanyakan mereka adalah masyarakat menengah atas yang berprofesi di sektor formal sebagai pengusaha, PNS, Polisi dan TNI. ${ }^{40}$

Dalam fase awal pendirian Bank Sampah (2019), masyarakat yang aktif menggerakkan dan menjadi nasabah bank sampah kebanyakan berasal dari RT 02 dan RW 03, yang mayoritasnya menengah ke bawah. Sedangkan, untuk RT 01 dan RT 04, tidak terlalu banyak masyarakat yang aktif mengikuti Bank Sampah. Masyarakat di RT 01 dan RT 04 kebanyakan membantu pada aspek dana dan program sedekah sampah untuk pengembangan Bank Sampah.

\section{Aset Komunitas Dalam Pengembangan Bank Sampah Songolikoer}

Proses pemetaan aset komunitas dilakukan secara kontinu, mulai dari tahap perumusan awal program Bank Sampah, hingga tahap pengembangan program Bank Sampah. Dari

\footnotetext{
${ }^{40}$ Agus Winarto, wawancara, tanggal 27 Januari 2020.
} 
proses pemetaan tersebut diperoleh beberapa jenis aset komunitas yang terdapat pada Bank Sampah Songolikoer, antara lain:

\section{a) Aset Manusia}

Pertama, adanya ibu-ibu kader posyandu dan kelompok remaja masjid yang secara aktif bergabung dalam kegiatan kader lingkungan Wonokusumo Kidul. Sejak berdiri pada awal tahun 2018, anggota kader lingkungan memiliki kegiatan membersihkan kampung setiap minggu. Anggota kader lingkungan berjumlah 20 orang, sebagian besarnya adalah remaja, namun ada pula ibu-ibu yang selama ini memang aktif sebagai kader posyandu. Anggota kader lingkungan secara rutin menyapu, membersihkan sampah, menyiram pot-pot di seluruh bagian kampung Wonokusumo Kidul 29 setiap hari minggu pagi. Namun, sayangnya sebelum adanya Bank Sampah, hanya anggota kader lingkungan saja yang aktif membersihkan kampung, sehingga kebersihan kampung hanya berjalan sebentar saja karena tidak diikuti oleh partisipasi masyarakat secara luas. ${ }^{41}$

Anggota kader lingkungan ini sudah memiliki ikatan yang kuat dan semangat untuk memajukan kampung. Semangat "berubah lebih baik", menjadi jargon yang selalu didengungkan oleh anggota kader lingkungan. ${ }^{42}$ Kepedulian anggota kader lingkungan pada sampah juga didorong adanya pengalaman melihat masyarakat Wonokusumo Kidul yang mendapat sindiran dari Wali Kota Surabaya karena persoalan kepedulian lingkungan yang rendah, yang

\footnotetext{
${ }^{41}$ Ibid., tanggal 17 April 2018.

42 Tri Djoyo Budiono, wawancara, tanggal 13 April 2018.
}

mana sindiran tersebut menjadi viral di media sosial. ${ }^{43}$

Generasi muda merupakan aset penting dalam pendirian dan pengembangan Bank Sampah Songolikoer, karena generasi muda memiliki potensi niat yang kuat, ketika hati mereka tersentuh mereka akan melakukan perubahan dengan ikhlas. Selain itu, remaja Wonokusumo Kidul memiliki tenaga yang energik untuk melaksanakan berbagai kegiatan pemilahan dan penimbangan sampah. Sedangkan ibu-ibu kader posyandu memiliki pengalaman berorganisasi yang baik dalam kegiatan PKK dan posyandu, serta kemampuan administrasi, pengelolaan keuangan yang baik, sehingga dapat dioptimalkan dalam membangun sistem bank sampah yang profesional dan transparant. ${ }^{44}$

Kedua, potensi kemampuan memilah dan menimbang sampah. Beberapa anggota kader lingkungan memiliki keterampilan tersebut, karena beberapa dari mereka ada yang berpengalaman bekerja sebagai pengepul sampah/rombeng dan pernah mengikuti pelatihan di Bank Sampah Induk. Selain itu, pada awal pendirian, bila ada kebingungan dalam klasifikasi jenis sampah dan nilainya, masih dimungkinkan untuk bertanya kepada Bank Sampah Induk Surabaya sebagai mitra kerja sama.

Ketiga, sumber daya manusia yang memiliki kemampuan teknis seperti: pencatatan, perhitungan keuangan, dan kemampuan menjahit. Kegiatan bank sampah, erat kaitannya dengan bentuk administrasi dan keuangan dari hasil perolehan sampah, sehingga dengan adanya kemampuan

${ }^{43}$ Agus Winarto, wawancara, tanggal 17 April 2018

${ }^{44}$ Ibid. 
tersebut sangat membantu kelancaran program bank sampah. Beberapa SDM yang bergerak di bank sampah ada yang lulusan SMK di bidang akutansi (Nessa dan Bu Romlah), sehingga dapat dioptimalkan dalam bidang administrasi pembukuan atau pencatatan. Sedangkan, kemampuan menjahit yang dimiliki oleh SDM (Rudi), selama ini diutamakan untuk menjahit karung-karung untuk menjadi wadah sampah yang lebih besar, agar memiliki daya tampung sampah yang lebih maksimal. Dengan kemampuan tersebut, dapat mengurangi kebutuhan pembelian karung besar untuk wadah sampah yang sudah dipilah. Sehingga, dapat menghemat dana pembelian karung pada masa-masa awal pendirian Bank Sampah.

Dalam perkembangan Bank Sampah, ditemukan potensi-potensi keterampilan teknis lainnya yang dapat digunakan untuk pengembangan program-program Bank Sampah. Terdapat beberapa masyarakat yang memiliki kemampuan untuk membuat kerajinan tangan dari sampah yang memiliki prospek untuk dijual, hal tersebut ditemukan saat diadakan lomba kerajinan dari sampah yang diikuti oleh berbagai masyarakat Wonokusumo Kidul. Selain itu, juga terdapat anggota masyarakat yang memiliki kemampuan dan pengalaman dalam hal membuat rancangan proposal kegiatan atau bantuan pemerintah serta mampu merincikan kebutuhan anggaran program. Kemampuan tersebut, dimanfaatkan untuk pembuatan proposal permohonan kerja sama Bank Sampah Songolikoer dengan perusahaan atau melalui program Corporate Social Responsibility (CSR).
Keempat, aset berupa para pemimpin atau leader kelompok yang memiliki kepedulian terhadap perbaikan lingkungan. Saat awal berdirinya Bank Sampah, ada Ketua PKK sekaligus Ketua Kader Lingkungan yang juga memiliki motivasi yang tinggi untuk mengadakan Bank Sampah. Dalam perkembangannya Ketua Remaja Masjid juga aktif dalam kegiatan Bank Sampah. Leader kelompok masyarakat merupakan aset kepemimpinan untuk menggerakkan anggota bank sampah lainnya.

Kelima, berdasarkan kesibukannya, masyarakat Wonokusumo Kidul dapat dibagi menjadi dua kelompok. Pertama, masyarakat yang pekerjaannya di rumah seperti berjualan makanan, pedagang kelontong, jualan jajan, ataupun kopi. Kecenderungan berjualannya pagi - siang sekitar jam 12.00 sehingga setelah itu waktunya luang. Selain itu ada kelompok ibu rumah tangga, yang mana pekerjaannya adalah merawat anak/keluarga. Ibu rumah tangga di wilayah ini masih memungkinkan bertetangga, mengikuti kegiatan kampung, bahkan sore dan malam masih memiliki waktu longgar. Ada juga, karyawan pabrik kitab, karyawan toko di Pasar Kapasan dan lain sebagainya, pada malam hari waktunya kosong. Selain itu, ada remaja yang memang banyak memiliki waktu luang sehingga lebih banyak menghabiskan waktunya di warung kopi. Sebelum ada kegiatan bank sampah, waktu kosong tersebut biasanya dimanfaatkan untuk mengobrol dengan tetangga ataupun mengopi di warung kopi. Namun, setelah adanya Bank Sampah, masyarakat bisa produktif tetapi juga tetap dapat berinteraksi dengan masyarakat yang selainnya. 
Sedangkan kelompok kedua adalah masyarakat menengah atas, mayoritas di luar RT 02 yang lebih sibuk, mengingat banyak di antara mereka yang merupakan pebisnis, memiliki jabatan di pemerintah kota dan perusahaan lain. ${ }^{45}$ Kelompok yang pertama tidak mengalami kesulitan baik secara ketersediaan waktu. Sedangkan, kelompok kedua kurang memungkinkan terlibat secara intensif dalam kegiatan Bank Sampah, karena cenderung tidak memiliki waktu panjang di rumah. Namun, sebenarnya kelompok kedua tersebut merupakan aset potensial untuk mendorong kreativitas atau inovasi program-program pengembangan bank sampah ke depannya.

\section{b) Aset Fisik}

Pertama, melimpahnya jumlah sampah di wilayah tersebut. Di wilayah tersebut terdapat TPS (Tempat Pembuangan Sampah Sementara), yang tidak hanya berasal dari sampah masyarakat Wonokusumo Kidul. Tak jarang, masyarakat sekitar lainnya memberikan barang-barang yang sudah tidak dipakai kepada masyarakat Wonokusumo Kidul, karena dipandang memiliki kekurangan secara ekonomi. Sampah yang selama ini seringkali dipandang sebagai masalah, di wilayah ini menjadi aset berharga, terlebih dengan jumlahnya yang berlimpah serta dapat diperoleh secara gratis.

Jumlah sampah yang melimpah dibuktikan dalam pelaksanaan penimbangan pertama (pada awal kegiatan bank sampah diuji coba), masyarakat dapat mengumpulkan sampah hingga lebih dari $100 \mathrm{~kg}$, yang jika dikonversi setara Rp 214.065,00. Jumlah

45 Tri Djoyo Budiono, wawancara, tanggal 17 Juni 2020. sampah ini terus berkembang pada pengumpulan selanjutnya hingga tiga kali lebih banyak dari jumlah tersebut. Serta, jumlah sampah di TPS juga masih sangat banyak, menunjukkan bahwa belum sepenuhnya dikumpulkan melalui Bank Sampah. Sebagai bank sampah baru, jumlah tersebut merupakan jumlah yang besar, mengingat target dari Bank Sampah Induk untuk sebuah bank sampah baru agar dapat berkerja sama dengan Bank Sampah Induk hanya $100 \mathrm{~kg}$, tiap kali pengumpulan. Jika awalnya sampah tersebut hanya mampu diangkut ke Bank Sampah Induk dengan motor Tossa, saat ini sudah menggunakan kendaraan pikap dengan ukuran yang makin besar.

Jumlah sampah melimpah ditunjang oleh lokasi kampung Wonokusumo Kidul yang berdekatan dengan pasar. Selain itu, masyarakat ada yang mata pencahariannya berjualan gorengan (hingga menghasilkan cukup banyak jelantah), membuka warung kopi (yang memiliki banyak sampah kemasan dan kaleng rokok) serta terdapat bisnis percetakan kitab (yang sering kali banyak sampah-sampah kertas seperti dupleks atau kitab yang rusak). Sampah yang ada di wilayah Wonokusumo Kidul dari berbagai jenis, baik sampah botol dan gelas plastik, kemasan, kertas, jelantah, karak, dan lain sebagainya.

Sebelum ada Bank sampah, belum banyak masyarakat yang peduli dengan adanya sampah. Hanya sedikit masyarakat yang mengumpulkan sampah, itupun sampahsampah yang memiliki nilai ekonomi jika dijual ke pengepul sampah, seperti: kardus, gelas/botol plastik serta besi. Namun, untuk sampah yang berbentuk kemasan, jelantah, dupleks, karak (nasi kering) dan beberapa 
jenis lain tidak dikumpulkan oleh masyarakat, sebab tidak dapat dijual ke pengepul sampah di sekitar. Menurut salah satu penggagas Bank Sampah Songolikoer menyampaikan bahwa: "Potensi sampah banyak, mengingat jumlah kepala keluarga yang ada di situ cukup banyak dan sering ada hajatan warga. Potensinya cukup besar, di RT 2 saja ada lebih dari 75-an KK, kalau mereka setiap hari memasak atau melakukan kegiatan sehari-hari, tentunya ada sampah organik dan anorganiknya, apalagi kalau ada hajatan, tentu lebih banyak lagi. ${ }^{\prime 46}$

Kedua, aset berupa tempat-tempat yang dapat digunakan untuk aktivitas meningkatkan ekonomi masyarakat, misal: Balai RW. Balai RW selama ini hanya dimanfaatkan untuk kegiatan lansia. Namun, sebenarnya potensial dimanfaatkan karena kondisi balai RW yang luas. Balai RW memiliki 1 ruang besar, 2 ruang kamar, serta halaman depan balai RW yang luas. Kamar-kamar tersebut memungkinkan menjadi tempat penyimpanan sampah yang sudah dipilah. Balai RW ini digunakan untuk kegiatan bank sampah pada awal pendirian sampai dengan 1 tahun. Namun, setelah ada pergantian kepengurusan RT dan RW, kegiatan bank sampah dipindahkan ke lahan kosong salah satu warga, agar tidak menggangu pelaksanaan kegiatan lain yang diselenggarakan oleh pengurus RW baru. Lahan kosong milik warga ini kemudian dimanfaatkan, sebagai gantinya bank sampah membayar sewa sejumlah Rp $150.000,00$ serta ditambah dengan membantu membersihkan kamar mandi umum dari pemilik lahan ini.

46 Tri Djoyo Budiono, wawancara, tanggal 13 April 2018.
Selain itu, ada salah satu rumah kosong cukup luas milik pemerintah di wilayah tersebut yang tidak terpakai. Namun, karena sangat gelap, dekat dengan makam serta TPS maka masyarakat enggan untuk menggunakannya. Terutama karena tempat tersebut dianggap menakutkan (angker). Kegiatan bank sampah dilaksanakan malam hari yang sebagian besar ibu-ibu, membuat masyarakat tidak mau menggunakan tempat tersebut. Namun, ada gambaran ke depannya bila dapat mengubah mindset masyarakat, pengurusan izin dan ada dana renovasi tempat tersebut. Maka, tempat tersebut berpotensi dimanfaatkan mengingat bangunannya yang cukup luas dan gratis.

c) Aset Finansial

Pertama, dana untuk pendirian Bank Sampah Songolikoer diperoleh dari “jimpitan" ${ }^{47}$ yang dikumpulkan sukarela dari anggota kader lingkungan setiap minggunya. Yang mana dari uang jimpitan tersebut digunakan untuk pelaksanaan kegiatan yang terkait lingkungan, salah satunya adalah modal untuk pendirian bank sampah.

Kedua, dana keuntungan kegiatan bank sampah. Keuntungan itu diperoleh dari usaha pemilahan sampah yang dilakukan pengurus bank sampah. Mengingat terkadang masyarakat menyetorkan sampah belum dipilah, jika belum dipilah maka harganya lebih murah. Sehingga, pemilahan tersebut dilaksanakan oleh pengurus dan bank sampah memperoleh keuntungan dari hal itu. Selain itu keuntungan juga berasal dari potongan $10 \%$

\footnotetext{
47 Jimpitan : iuran sukarela dari anggota kader lingkungan yang diambil setiap pelaksanaan kegiatan kader lingkungan.
} 
yang dibebankan ke masing-masing nasabah sebagai biaya administrasi atas layanan yang diberikan oleh bank sampah.

Ketiga, berasal dari sedekah sampah yang diberikan oleh masyarakat sekitar yang tergolong mampu dan potensi jaringan teman-teman anggota remaja masjid yang memiliki kemampuan memberikan bantuan dana maupun sedekah sampah. Di wilayah RT 01 dan 04, RW 06 Wonokusumo Kidul terdapat sebagian masyarakat yang tinggal di wilayah perumahan dan tergolong mampu. Mereka ini banyak yang berprofesi sebagai pengusaha, polisi maupun TNI. Beberapa masyarakat sekitar memiliki kesadaran terhadap mengumpulkan sampah, namun karena secara ekonomi tergolong mampu maka mereka tidak membutuhkan tambahan pemasukan dari sampah. Sampah tersebut berpotensi didonasikan untuk pemasukan operasional bank sampah. Bank Sampah Songolikoer juga membuat program sedekah sampah yang disosialisasikan baik lewat media sosial maupun secara langsung ke masyarakat.

\section{d) Aset Sosial}

Pertama, hidupnya berbagai kegiatan sosial keagamaan. Misal: pengajian sambang dulur, yasin dan tahlil, kegiatan peringatan hari besar Islam, PKK, posyandu dan lansia. Kegiatan-kegiatan ini dilaksanakan secara rutin tiap minggu atau bulan.

Kegiatan sambang dulur, yang diadakan setiap hari jumat, dari rumah ke rumah anggota remaja masjid. Kegiatan sambang dulur bertujuan untuk mengikatkan silaturahmi, meningkatkan nilai-nilai keislaman dan semangat mengubah kampung menjadi lebih baik. Dalam kegiatan ini biasanya diisi dengan tausiah yang disampaikan oleh penggagas remaja masjid dan Bank Sampah Songolikoer.

Kegiatan posyandu dan PKK yang selalu terselenggara tiap minggu, digerakkan oleh ibu-ibu kader posyandu. Subjek penggerak yang berpengaruh terhadap berjalannya kegiatan-kegiatan sosial di masyarakat Wonokusumo Kidul antara lain: Ketua Takmir, Ketua RW, Ketua Pengajian Ibu-ibu, Ketua Remaja Masjid Ar-Rahman, Penggagas Remaja Masjid Ar-Rahman, dan pengurus kader posyandu. Kegiatan yang aktif di masyarakat ini kecenderungan diikuti oleh para remaja dan ibu-ibu. Oleh karenanya, pendirian dan pengembangan Bank Sampah Songolikoer lebih banyak melibatkan masyarakat dari kalangan remaja dan ibu-ibu, baik sebagai pengurus maupun nasabahnya. ${ }^{48}$

Kedua, masyarakat sebagian besar berangkat dari masyarakat yang kekurangan secara ekonomi, tetapi juga memiliki semangat kerja keras untuk menutupi kebutuhan ekonomi keluarga. Ibu-ibu ikut membantu para suami berjualan di pasar, menjadi pengepul sampah atau bekerja di percetakan. Sedangkan para remaja dalam menjalankan kegiatan remaja masjid dan kader lingkungan sangat bersungguh-sungguh serta cekatan dalam hal teknis.

Ketiga, sebagai masyarakat menengah ke bawah. Masyarakat secara potensi tidak malu jika harus mengumpulkan dan memilah sampah. Masyarakat juga secara karakter tidak mudah jijik dengan kegiatan yang terkait dengan mengumpulkan sampah. Keempat, dengan kondisi

${ }^{48}$ Agus Winarto, wawancarai, tanggal 18 Desember 2018. 
masyarakat yang sebagian besar tergolong menengah ke bawah maka pemasukan ekonomi adalah hal yang dipandang sangat penting dan menjadi kebutuhan dasar untuk dipenuhi. Hal itu ditunjukkan dari budaya masyarakat ketika menjelang bulan Ramadan dan pada saat hari raya Idulfitri, banyak masyarakat yang berlomba-lomba mencari rezeki dengan cara menjual bunga untuk tradisi nyekar di makam, membersihkan makam yang ada di wilayah tersebut maupun bersegera berkunjung ke rumah masyarakat yang lain untuk mendapatkan uang lebaran. ${ }^{49}$

Masyarakat akan bergerak jika sebuah kegiatan benar-benar dapat memberikan manfaat ekonomi. Meskipun di awal menjalankan kegiatan bank sampah, mungkin merasa ribet, namun dengan prospektus ekonomi yang tinggi maka masyarakat dengan senang hati menjalankan kegiatan bank sampah. ${ }^{50} \mathrm{Hal}$ ini terbukti dengan terus bertambahnya nasabah Bank Sampah Songolikoer, dari yang awalnya hanya 16 orang berkembang hingga 61 orang. Selain itu, jumlah sampah yang terkumpul juga makin meningkat. Masyarakat makin berlomba-lomba mendapatkan pemasukan dari bank sampah.

Kelima, nilai-nilai yang dimiliki kelompok orang tua untuk memperbaiki kampung, karena kekhawatiran kalau anak-anak mereka terjebak narkoba. Mereka menyampaikan: "kami ini miskin, kalau anak kami terjerumus narkoba maka bagaimana lagi jadinya hidup kami." 51

49 Tri Djoyo Budiono, wawancara, tanggal 27 April 2020.

${ }^{50}$ Ibid., tanggal 10 Desember 2018.

51 Ibid., tanggal 13 April 2018.
Keenam, budaya guyub dan gotong royong yang ada di masyarakat. ${ }^{52}$ Masyarakat memiliki interaksi sosial yang sangat guyub karena jarak antar rumah sangat berdekatan, jalan gang kampung yang sempit, serta memiliki berbagai aktivitas sosial bersama (seperti: pengajian, PHBI, dan lain-lain). Tak jarang masyarakat saling bercengkerama, ngobrol di depan rumah antar tetangga. Dengan kultur ini, arus informasi antar masyarakat menyebar sangat cepat, dari mulut ke mulut.

Sedangkan, budaya gotong royong tecermin dari berbagai kegiatan kampung seperti pengajian, perayaan PHBI maupun ketika ada yang kesusahan, misalnya: kematian. Berbagai elemen masyarakat, dari beragam kelas ekonomi, aktif berkontribusi dalam kegiatan bersama maupun menolong sesama. Kontribusi tersebut dapat dalam bentuk tenaga, dana, kemampuan dan makanan. Nilai gotong royong ini yang juga dimanfaatkan untuk mengembangkan bank sampah. Setiap ada perayaan ulang tahun atau sosialisasi bank sampah, berbagai elemen masyarakat dilibatkan. Masyarakat menengah atas, tak segan-segan untuk menghadiri kegiatan yang dilaksanakan dan membantu menyumbangkan dana untuk pelaksanaan kegiatan. Sedangkan, masyarakat menengah bawah bergotong royong memberikan tenaga atau membawakan makanan.

Masyarakat Wonokusumo Kidul berasal dari berbagai etnis, meliputi: Arab, Madura dan Jawa. Sekalipun dari berbagai etnis, namun ikatan sosial masyarakat cukup baik, khususnya dalam hal melaksanakan

52 Agus Winarto, wawancara, tanggal 18 Desember 2018. 
kegiatan-kegiatan keagamaan dan kemasyarakatan di wilayah tersebut. Jumlah masyarakat yang berasal dari Madura cukup dominan. Sehingga, banyak dijumpai kebudayaan, makanan khas Madura dan dialek/bahasa Madura yang digunakan dalam keseharian.

\section{e) Aset Institusi}

Adanya dukungan aset institusi lokal pada konteks masyarakat perkotaan menengah ke bawah cukup berperan penting dalam kelancaran pengembangan masyarakat. Saat awal pendirian Bank Sampah Songolikoer dapat berjalan dengan lancar dan tidak mendapatkan tanggapan buruk dari masyarakat, mengingat saat itu salah satu penggagas bank sampah, yaitu Bapak Agus merupakan ketua RW 06 Wonokusumo Kidul Surabaya. Masyarakat merasa segan dengan beliau, sehingga cenderung mendukung program bank sampah.

Selain itu, Ketua RW 06 memiliki kedekatan dengan anggota kader lingkungan. Kedekatan tersebut ditunjukkan dari langkah-langkah yang dilakukan ketika anggota kader lingkungan bangun kesiangan pada hari minggu sehingga telat untuk melakukan action bersih-bersih lingkungan. Saat itu, Ketua RW langsung mendatangi rumah masing-masing anggota dan membangunkan mereka, seizin orang tuanya. Ketua RW senantiasa memberikan contoh semangatnya dalam membersihkan lingkungan. Tiap ada pelaksana kegiatan membersihkan kampung, ketua RW tidak pernah terlewatkan ikut turun tangan juga membantu. Ketua RW berperan dalam kegiatan kader lingkungan baik secara tenaga, kepemimpinan, pikiran bahkan dana..$^{53}$

Institusi lain yang mendukung saat awal pendirian bank sampah adalah ketua RT 02 . Ketua RT 02 memberikan dukungan terhadap kegiatan pendirian Bank Sampah Wonokusumo Kidul, yang mana saat itu kegiatan terselenggara di balai RW 06 yang berada di wilayah teritorial RT $02 .^{54}$

Selain itu, juga ada dukungan dari birokrasi kelurahan. Hal itu dikarenakan bapak Agus sering menyampaikan informasi di grup kelurahan sehingga mendapatkan tanggapan yang positif dari pengurus kelurahan. Pada saat kegiatan ulang tahun bank sampah yang pertama, ada perwakilan kelurahan yang hadir serta memberikan sambutan positif terhadap kegiatan Bank Sampah Songolikoer. Hal ini juga makin memotivasi nasabah dan pengurus untuk terus mengembangkan Bank Sampah Songolikoer..$^{55}$

\section{f) Aset Spiritual}

Salah satu kegiatan yang paling aktif di kampung ini adalah kegiatan remaja masjid. Pengurus bank sampah sebagian besar berasal dari remaja masjid. Yang mana dalam kegiatan Remaja Masjid, para remaja ditanamkan nilai-nilai tentang semangat berubah lebih baik, bermanfaat bagi lingkungan, kecintaan pada nilai-nilai akhirat dan istikamah. Para anggota remaja masjid senantiasa ditanamkan nilai-nilai: "kita ini orang miskin, untuk sedekah amatlah susah, apalagi yang bisa diberikan

\footnotetext{
${ }^{53}$ Agus Winarto, wawancara, tanggal 17 April 2018.

54 Ibid.

55 Ibid., tanggal 27 Januari 2020.
} 
jika bukan tenaga yang bisa menjadi amal sholeh." ${ }^{56}$

Selain itu, para pengurus bank sampah selalu mendapatkan motivasi dari salah satu penggagas kader lingkungan sekaligus pembina remaja masjid Ar-Rahman, bahwa: Bank sampah ini kegiatan sosial, kalau untuk mendapatkan untung mungkin akan susah. Namun, kita harus ingat bahwa yang menggerakkan kita adalah "Iillāhi ta'āla." Nilai "Iillāhi ta'āla" ini sangat tecermin dalam aktivitas para pengurus Bank Sampah Songolikoer, meski mereka tidak pasti mendapatkan bayaran namun secara rutin dua kali seminggu mereka melaksanakan pengumpulan sampah pada hari rabu dan jumat.

Mengingat orientasinya bukan keuntungan tapi manfaat sosial dan pahala dari Allah maka ketika mereka mendirikan bank sampah sebisa mungkin mereka tidak merugikan masyarakat sekitar yang sebelumnya telah mengumpulkan sampah. Misalnya: 1) Untuk masyarakat yang sebelum adanya bank sampah juga mengumpulkan sampah (mengumpulkan sampah pada saat ada hajatan kampung), maka pengurus bank sampah justru membantu masyarakat tersebut untuk mengumpulkannya, memberikan kepada yang biasa mengumpulkan sampah dan tidak berkompetisi untuk mendapatkan sampah tersebut. 2) Harga yang dibuat untuk masyarakat yang dari awal sudah berprofesi mengumpulkan sampah adalah harga tertinggi, sesuai dengan biasanya mereka menjual pada pengepul. Para pengurus bank sampah bahkan harus menanggung kerugian dari selisih harga

56 Tri Djoyo Budiono, wawancara, tanggal 13 April 2018. antara harga di pengepul dan pada Bank Sampah Induk, khusus untuk membayar beberapa masyarakat yang sebelumnya sudah berprofesi sebagai pengumpul sampah. ${ }^{57}$ Pengurus terus berupaya untuk memikirkan inovasi agar tidak sampai mengalami kerugian dengan mengoptimalkan sedekah sampah dan meningkatkan ketelitian pemilahan sampah agar nilai keuntungannya makin besar.

Nilai ketiga yang dimiliki pengurus Bank Sampah Songolikoer adalah nilai-nilai istikamah. Nilai-nilai istikamah ini tertanam sehingga membuat pengurus memiliki kesadaran bahwa upaya memperbaiki kampung dan mendirikan bank sampah, bukanlah hal yang mudah, di dalamnya akan banyak hambatan yang membuat enggan berjalan secara rutin dan terus menerus. Oleh karena itu, perlu untuk senantiasa sadar bahwa "Harus istikamah dalam menjalankan kegiatan ini. Apapun yang terjadi harus ada yang memulai dan terus istikamah meski harus seorang diri. ${ }^{158}$

Masyarakat Wonokusumo Kidul sangat menjunjung nilai-nilai keislaman. Banyak kegiatan keagamaan yang hidup di masyarakat mulai dari perayaan $\mathrm{PHBI}$, pengajian yasin tahlil, ketika menjelang Ramadan masyarakat memiliki kebiasaan Nyadran (pergi ke makam) dan Megengan, ketika Ramadan masyarakat juga aktif melaksanakan teraweh dan tadarus. Tokoh agama di masyarakat, pengurus takmir, masyarakat yang gemar ke masjid juga sangat disegani oleh masyarakat. ${ }^{59}$ Selain itu, terdapat pula semangat atau primordialisme untuk menjadikan kampung

57 Tri Djoyo Budiono, wawancara, tanggal 13 April 2018.

$58 \mathrm{lbid}$.

59 Ibid., tanggal 13 April 2018 dan 27 April 2020. 
Wonokusumo Kidul menjadi kampung yang lebih baik. Nilai-nilai bahwa kampung Wonokusumo Kidul bisa berubah lebih baik, menjadi salah satu nilai yang kuat tertanam pada anggota remaja masjid yang aktif mengikuti kegiatan kader lingkungan maupun bank sampah. "Berubah lebih baik" menjadi moto dan semangat remaja-remaja di Wonokusumo Kidul untuk terus berproses mengubah kampung.

Harapan mereka, jika dulu kampung Wonokusumo Kidul, diberi label oleh masyarakat sebagai Kampung Maling maka ke depannya kampung ini harus selalu berubah ke arah yang lebih baik. Menurut penuturan Ketua Kader Lingkungan, para anggota kader lingkungan memiliki semangat kuat menjadikan kampung Wonokusumo Kidul menjadi kampung wisata, seperti kampung-kampung wisata lain yang indah, bersih, dan warganya tertib. ${ }^{60}$

g) Aset Teknologi

Sebagai wilayah perkampungan yang berada di perkotaan, masyarakat Wonokusumo Kidul memiliki aset teknologi gadget dan internet. Cukup banyak masyarakat yang memiliki gadget. Selain itu, di berbagai warung kopi di sekitar wilayah ini juga menyediakan fasilitas internet/WiFi gratis. Aset teknologi gadget ini yang dimanfaatkan oleh pengurus bank sampah untuk menyosialisasikan Bank Sampah Songolikoer kepada masyarakat luas melalui berbagai media sosial, seperti: YouTube, web, Facebook dan Instagram. Meskipun, saat ini proses memanfaatkan media sosial masih tahap awal dan masih

60 Rudianto (ketua kader lingkungan Wonokusumo Kidul), wawancara oleh Wahanani, tanggal 12 Mei 2018. terus proses dikembangkan dan ditingkatkan kualitasnya. Penggunaan media sosial sejauh ini untuk menyosialisasikan kegiatan bank sampah, menghimpun sedekah Sampah, maupun donasi untuk program-program pengembangan bank sampah. Selain itu, gadget juga digunakan untuk mempermudah koordinasi pengurus Bank Sampah Songolikoer.

\section{h) Aset Lingkungan}

Wilayah Wonokusumo Kidul tidak memiliki aset lingkungan yang menonjol. Wilayahnya yang berada di Surabaya Utara, cenderung panas dan gersang, sekalipun terdapat beberapa pohon yang tumbuh, namun jumlahnya tidak banyak. Belum dijumpai panorama lingkungan ataupun suasana lingkungan yang sehat, baik yang alami maupun buatan di wilayah Wonokusumo Kidul. Kondisi lingkungannya justru memiliki banyak permasalahan terkait dengan sampah, kepadatan penduduk yang tinggi maupun ketertiban masyarakatnya untuk menjaga lingkungan. Wilayah di kampung ini dekat dengan makam umum yang sangat luas dan ramai dikunjungi masyarakat luar di waktu-waktu tertentu. Selain itu, wilayah di sekitar makam cukup luas serta berpotensi dimanfaatkan untuk kegiatan penghijauan namun selama ini belum teroptimalkan dengan baik dalam program pengembangan bank sampah maupun program-program lingkungan lainnya di wilayah ini. 


\section{Peranan Aset Komunitas Dalam Pengembangan Bank Sampah Songolikoer}

Peranan aset komunitas dapat dilihat dari bagaimana aset tersebut memiliki guna atau manfaat dalam proses pengembangan masyarakat, mulai dari tahap sosialisasi awal hingga pengembangan bank sampah. Tahap sosialisasi awal merupakan upaya membangun kesadaran masyarakat agar mau bergabung pada bank sampah. Aset fisik berupa adanya tempat pembuangan sampah sementara yang memiliki jumlah sampah melimpah menjadi salah satu daya tarik masyarakat untuk menjadi nasabah bank sampah. Sampah yang selama ini berlimpah dan beberapa jenis sampah awalnya dipandang tidak memiliki nilai ekonomi, ternyata memiliki nilai ekonomi jika dikumpulkan dan ditabung di bank sampah. Sosialisasi dapat berjalan lancar karena adanya kesesuaian antara kegiatan pengembangan masyarakat dengan aset manusia di wilayah tersebut, yang kebanyakan adalah masyarakat menengah ke bawah, didominasi kalangan remaja dan ibu-ibu yang memiliki keinginan mendapatkan pemasukan ekonomi. Selain itu, sebagian masyarakat telah memiliki kemampuan dalam memilah sampah, ketersediaan waktu serta adanya mentalitas tidak takut terhadap sampah atau kotor. Aset sosial seperti: ikatan solidaritas dan budaya guyub mempercepat upaya sosialisasi kepada seluruh warga. Dukungan aset institusi yaitu RT dan RW yang mendukung kegiatan bank sampah, dapat membangkitkan kepercayaan masyarakat untuk menjadi nasabah bank sampah.

Pada tahap pelatihan teknis, aset manusia berupa anggota kader lingkungan.
Pengalaman beberapa anggota kader lingkungan yang pernah bekerja menjadi rombeng dapat mempercepat pelatihan teknis di bidang pemilahan sampah dan pengenalan sistem kerja bank sampah. Selain itu, mentalitas dalam hal memilah sampah juga tidak mengalami masalah karena sebagian besarnya merupakan masyarakat menengah ke bawah yang tidak takut terhadap kotor. Dalam hal pelatihan teknis kemampuan administrasi dan pencatatan, ada beberapa SDM yang memiliki kemampuan di bidang akuntansi sehingga dapat diberdayakan pada tahap ini.

Pada tahap pelaksanaan, berbagai jenis aset memiliki peran untuk kesuksesan pelaksanaan bank sampah. Pertama, Aset Fisik berupa gedung balai RW dimanfaatkan untuk proses pelaksanaan bank sampah pada fase awal pendirian bank sampah. Bagian halaman depan balai RW digunakan untuk menimbang dan memilah, sedangkan ruang kamar kosongnya digunakan untuk menyimpan sampah yang sudah dipilah dan dibersihkan sebelum diangkut ke Bank Sampah Induk. Penggunaan aset fisik berupa balai RW ini juga tidak dapat dilepaskan dari adanya dukungan aset institusi saat itu, yaitu perangkat RT-RW yang memberikan izin penggunaan balai RW sebagai tempat pelaksanaan kegiatan bank sampah pada fase awal.

Kedua, aset sosial meliputi ikatan solidaritas yang kuat dan hidupnya berbagai kegiatan kemasyarakatan dapat digunakan untuk media informasi kepada masyarakat dari mulut ke mulut terkait waktu pelaksanaan maupun sistem bank sampah. Hal ini lebih efisien dibandingkan sosialisasi menggunakan forum maupun media sosial, 
karena tidak semua masyarakat, khususnya nasabah ibu-ibu memiliki gadget. Selain itu, aset sosial berupa kepercayaan antar masyarakat menjadi aset penting dalam menjalankan sistem bank sampah yang mana pendapatannya berupa tabungan dan hanya dapat diambil pada waktu tertentu.

Ketiga, aset finansial seperti uang jimpitan anggota kader lingkungan maupun hasil sedekah sampah menjadi modal pembelian infrastruktur maupun konsumsi pengurus dalam pelaksanaan bank sampah. Keempat, kemampuan-kemampuan teknis seperti menjahit karung, mencatat, menimbang, memilah menunjang kelancaran dalam pelaksanaan bank sampah. Beberapa jenis kemampuan tersebut dapat menghemat kebutuhan finansial dalam pelaksanaan kegiatan bank sampah, misalnya kemampuan menjahit karung.

Keempat, aset spiritual memiliki peranan memberikan semangat pelaksanaan kegiatan bank sampah. Kegiatan bank sampah merupakan kegiatan sosial kemasyarakatan, keuntungan finansial yang didapatkan oleh pengurus tidaklah seberapa dibandingkan dengan waktu dan tenaga yang dikeluarkan. Yang banyak menikmati manfaatnya adalah masyarakat, bukan pengurus bank sampah. Namun, dengan adanya nilai-nilai "lillāhi ta'āla", istikamah, dan semangat mengubah kampung lebih baik sebagai amal jariyah dapat membuat berjalannya bank sampah secara istikamah.

Aset sosial, seperti: kegiatan pengajian sambang dulur, menjadi media untuk terus membangun aset spiritual masyarakat, khususnya pengurus bank sampah tetap istikamah dalam melaksanakan kegiatan bank sampah. Keenam aset teknologi berupa gadget dan internet juga dimanfaatkan oleh pengurus untuk koordinasi sehingga memperlancar pelaksanaan bank sampah. Pada tahap pengembangan, bank sampah mengembangkan beberapa program antara lain: menjual hasil kerajinan tangan dari sampah, kegiatan simpan pinjam bayar sampah, dan mulai mencoba membuat proposal kerja sama dengan perusahaan untuk mendapatkan dana Corporate Social Responsibility (CSR). Pada tahap ini, beberapa aset yang sebelumnya belum dimanfaatkan mulai dioptimalkan peranannya.

Pertama, aset kemampuan berupa kemampuan membuat kerajinan dari sampah dan membuat proposal kerja sama antar lembaga. Kedua, aset finansial berupa sedekah sampah dan donasi dari masyarakat ekonomi menengah atas di wilayah Wonokusumo Kidul. Aset finansial ini dimanfaatkan untuk dana pengembangan bank sampah, seperti pengadaan acara ulang tahun Bank Sampah Songolikoer (sekaligus di dalamnya ada upaya sosialisasi prospektus bank sampah untuk ke depannya mencapai cita-cita kampung wisata), pelaksanaan lombalomba untuk menggali potensi masyarakat seperti lomba membuat kerajinan tangan dari sampah, serta sebagai dana untuk menyewa lahan baru dalam melaksanakan kegiatan bank sampah.

Selain mengandalkan aset finansial, dalam pengembangan bank sampah juga mengandalkan aset sosial berupa nilai-nilai gotong royong. Dalam setiap adanya kegiatan bank sampah, tak sedikit masyarakat yang berkontribusi bukan hanya 
dana namun juga tenaga dan makanan, termasuk dalam proses pengadaan kegiatan-kegiatan seperti syukuran ulang tahun bank sampah maupun lomba-lomba yang diadakan bank sampah. Selain itu, aset sosial berupa kepercayaan dan solidaritas antar sesama menjadi salah satu modal untuk menggagas program baru bank sampah dalam bentuk simpan pinjam bayar sampah. Dalam pengembangan program simpan pinjam ini, pinjaman yang diberikan berasal dari tabungan nasabah bank sampah, serta harus dibayar dengan mencicil melalui membayar dengan sampah. Syarat peminjam haruslah nasabah yang telah aktif mengumpulkan sampah dalam beberapa bulan sebelumnya, besaran pinjaman yang diberikan bergantung pada jumlah sampah yang biasanya mereka kumpulkan.

Proses pengembangan bank sampah juga makin baik karena adanya dukungan dari institusi, seperti pihak kelurahan yang memberikan semangat untuk mengembangkan bank sampah hingga ke depannya dapat menjadi kampung wisata. Selain itu, pada tahap pengembangan ini, Bank Sampah Songolikoer mulai mencoba mengenalkan diri kepada khalayak yang lebih luas melalui berbagai platform media sosial, seperti YouTube, Facebook, web, Instagram. Salah satu aset yang dimanfaatkan dalam pengembangan program tersebut adalah aset teknologi berupa gadget dan akses internet, serta adanya aset manusia berupa para remaja yang memiliki kemampuan dalam menggunakan gadget. Kegiatan pengembangan program-program bank sampah dapat terus berjalan dikarenakan adanya aset spiritual berupa nilai-nilai untuk senantiasa memberikan manfaat bagi kampung Wonokusumo Kidul dan nilai istikamah yang mendorong para pengurus Bank Sampah Songolikoer untuk senantiasa mengembangkan bank sampah menjadi lebih maju, bahkan harapannya mampu mengubah kampung Wonokusumo Kidul menjadi kampung wisata.

Dari adanya peranan aset komunitas yang dipotimalkan bahkan dikombinasikan dalam kegiatan pengembangan bank sampah, ada dampak positif terhadap meningkatnya kesejahteraan masyarakat, baik aspek ekonomi, sosial dan lingkungan antara lain: pertama, nasabah telah memperoleh tambahan pendapatan tabungan sampah, dalam satu semesternya antara Rp $200.000,00-R p \quad 1.000 .000,00$ per orangnya. Hingga saat ini sudah dilaksanakan dua kali (dua semester) pembagian tabungan nasabah bank sampah. Jumlah tersebut bagi masyarakat menengah ke bawah merupakan jumlah yang cukup besar. Belum lagi jika masyarakat mampu membuat kerajinan dari sampah yang dapat laku dijual maka pendapatan masyarakat akan makin besar. Jumlah nasabah yang menerima manfaat mencapai 61 orang. Sedangkan akumulasi tabungan Bank Sampah Songolikoer tiap kali penimbangan sampah oleh Bank Sampah Induk Surabaya antara lain: 
Tabel 1 - Akumulasi Tabungan Bank Sampah Songolikoer pada Bank Sampah Induk

\begin{tabular}{|c|c|c|}
\hline Tanggal & Debit & Saldo \\
\hline 25 Mei 2019 & Rp. 476.000 & Rp. 503.549 \\
\hline 29 Juni 2019 & Rp.464.484 & Rp. 968.033 \\
\hline 27 Juli 2019 & Rp. 498.051 & Rp. 1.466.084 \\
\hline $\begin{array}{l}31 \text { Agustus } \\
2019\end{array}$ & Rp. 647.868 & Rp. 2.113.952 \\
\hline $\begin{array}{l}15 \text { September } \\
2019\end{array}$ & Rp. 402.229 & Rp. 2.516. 181 \\
\hline $\begin{array}{l}29 \text { September } \\
2019\end{array}$ & Rp. 1.154.101 & Rp. 3.670.282 \\
\hline $\begin{array}{l}28 \text { Oktober } \\
2019\end{array}$ & Rp. 779.274 & Rp. 4.449 .556 \\
\hline $\begin{array}{l}3 \text { November } \\
2019\end{array}$ & Rp. 420.227 & Rp. 4.869 .783 \\
\hline $\begin{array}{l}13 \text { Oktober } \\
2019\end{array}$ & Rp. 778.604 & Rp. 5.648.337 \\
\hline $\begin{array}{l}22 \text { November } \\
2019\end{array}$ & Rp. 476.308 & Rp. 6.124.695 \\
\hline $\begin{array}{l}8 \text { Desember } \\
2019\end{array}$ & Rp. 829.074 & Rp. 6.953.769 \\
\hline $\begin{array}{l}21 \text { Desember } \\
2019\end{array}$ & Rp. 600.800 & Rp. 7.554.569 \\
\hline $\begin{array}{l}5 \text { Januari } \\
2019\end{array}$ & Rp. 439.390 & Rp. 7.993.959 \\
\hline $\begin{array}{l}25 \text { Januari } \\
2020\end{array}$ & Rp. 1.111.696 & Rp. 9.105.655 \\
\hline $\begin{array}{l}2 \text { Februari } \\
2020\end{array}$ & Rp. 224. 607 & Rp. 9.330.262 \\
\hline $\begin{array}{l}15 \text { Februari } \\
2020\end{array}$ & Rp. 575.636 & Rp. 9.905.898 \\
\hline
\end{tabular}

Kedua, dalam aspek sosial dengan adanya Bank Sampah Songolikoer makin menguatkan solidaritas antar masyarkat. Hal itu dikarenakan masyarakat bisa bertemu di bank sampah dua kali setiap minggu. Selain itu, masyarakat kelas menengah atas dan bawah tak jarang bertemu bersama dalam kegiatan-kegiatan sosialisasi bank sampah serta saling bekerja sama memberikan bantuan dalam berbagai kegiatan bank sampah. Terlebih dengan adanya kegiatan simpan pinjam dengan membayar sampah, juga dapat membantu masyarakat yang memiliki kesulitan dalam keuangan.
Ketiga, pada aspek lingkungan. Bank Sampah Songolikoer menyelenggarakan berbagai kegiatan, seperti: edukasi tentang sampah, kunjungan ke beberapa kampung wisata, kunjungan ke Bank Sampah Induk Surabaya, sosialisasi tentang Kampung Wisata. Hal itu mampu menumbuhkan kesadaran masyarakat terhadap nilai ekonomi dari sampah. Mengubah mindset bahwa sampah yang melimpah bukan masalah melainkan aset. Meningkatkan kepedulian masyarakat Wonokusumo Kidul terhadap lingkungan karena sering mengikuti kegiatan yang membahas isu-isu lingkungan dan bank sampah. Terbangunnya cita-cita bersama untuk menjadikan Wonokusumo Kidul menjadi kampung wisata. Jumlah masyarakat yang bersedia untuk aktif membantu menjadi pengurus bank sampah juga terus mengalami peningkatan.

\section{Kesimpulan}

Dalam konteks pengembangan masyarakat Islam dalam bentuk bank sampah, terdapat berbagai aset yang dapat dioptimalkan untuk menunjang keberhasilan bank sampah, antara lain: 1) aset fisik (potensi banyaknya sampah yang ada di masyarakat perkotaan, bangunan-bangunan yang bisa dioptimalkan sebagai tempat pengembangan masyarakat); 2) aset manusia (kemampuan teknis terkait bank sampah, kemampuan berorganisasi, ketersediaan waktu, pengetahuan/ kesadaran terhadap persoalan lingkungan, kemampuan untuk berinovasi, kekuatan tenaga, serta mentalitas); 3) aset finansial (sedekah sampah, keuntungan bank sampah maupun iuran jimpitan anggota kader lingkungan); 4) aset sosial (berupa nilai-nilai solidaritas, kepercayaan, gotong royong termasuk kelompok-kelompok sosial yang aktif di masyarakat); 5) aset institusi (dukungan dari aparat atau institusi formal 
seperti RT, RW, kelurahan maupun lembaga tertentu yang ada di masyarakat); 6) aset spiritual (berupa semangat untuk mengubah kampung karena "iillāhi ta'āla" serta semangat senantiasa istikamah); 7) aset teknologi berupa gadget dan internet.

Masing-masing aset memiliki peranan dalam tahapan pengembangan Bank Sampah Songolikoer. Aset yang cukup berperan dominan dalam upaya pengembangan bank sampah adalah aset manusia, aset sosial, dan spiritual. Aset manusia dan aset sosial sebagai sumber daya utama untuk menggerakkan kegiatan bank sampah mulai tahap sosialisasi, pelatihan teknis, pelaksanaan kegiatan, pemantauan dan evaluasi bahkan pada aspek pengembangan masyarakat. Dengan adanya aset manusia dan sosial dapat menghemat kebutuhan modal secara finansial untuk berjalannya kegiatan bank sampah. Sedangkan aset spiritual dapat memompa semangat masyarakat untuk terus bergerak menjalankan kegiatan pengembangan masyarakat sekalipun dengan sumber daya terbatas, keuntungan pengurus yang minim serta membutuhkan proses yang panjang untuk dapat meningkatkan kesejahteraan masyarakat, melalui bank sampah.

Aset finansial yang berupa sedekah dan jimpitan dapat menjadi modal untuk melaksanakan berbagai kegiatan bank sampah serta pengembangannya. Namun, jumlah aset finansial ini tidak pasti sehingga tidak menjadi modal utama dalam kegiatan pengembangan masyarakat melalui bank sampah. Aset fisik, berupa sampah akan selalu ada dan jumlahnya cukup besar, di masyarakat perkotaan akan sangat mudah dijumpai sampah. Namun tanpa adanya aset-aset yang selainnya maka aset fisik tidak akan ada artinya, karena kegiatan pengembangan masyarakat tidak akan dapat berjalan dengan baik dan berkelanjutan. Sedangkan, aset teknologi sekalipun jumlahnya terbatas masih dapat ditutupi dan dikembangkan jika memiliki aset-aset yang selainnya, misalnya: aset teknologi komunikasi dapat ditutupi dengan adanya budaya guyub yang ada di masyarakat, ataupun dapat dibeli jika masyarakat berhasil meningkat kesejahteraannya dari bank sampah.

Dari peranan berbagai aset dalam pengembangan masyarakat, memiliki dampak pada meningkatnya kesejahteraan masyarakat baik dalam hal pendapatan materiil maupun aspek sosial dan lingkungan. Pengembangan masyarakat yang berhasil dalam meningkatkan kesejahteraan masyarakat sama dengan mewujudkan nilai-nilai Islam yang rahmatan li al-ālamìn.

Mengingat kajian sebelumnya, lebih banyak berfokus pada aset sosial, finansial dan alam. Temuan penelitian ini dapat memperkaya kajian peranan aset manusia, sosial, dan spiritual sebagai aset utama dalam pengembangan masyarakat Islam. 


\section{Bibliografi}

Adi, Isbandi Rukmianto. Intervensi Komunitas \& Pengembangan Masyarakat Sebagai Upaya Pemberdayaan Masyarakat. Jakarta: PT Raja Grafindo Persada, 2013.

Budiono, Tri Djoyo. (penggagas Bank Sampah Songolikoer, penggerak remaja masjid untuk aktif pada kader lingkungan). Wawancara oleh Wahanani. Tanggal 13 April 2018.

Cahyono, Budhi dan Ardian Adhiatma. "Peran Modal Sosial Dalam Peningkatan Kesejahteraan Masyarakat Petani Tembakau di Kabupaten Wonosobo." Proceedings of Conference in Business, Accounting and Management (CBAM), vol. 1, no. 1 (Desember 2012): 131-144. http://jurnal.uninsula.ac.id/index.php/cbam/article/view/128

Dahlan, Jaeni. "Pemanfaatan Aset Komunitas Melalui Pendekatan Appreciative Inquiry Dalam Penanggulangan Kemiskinan di Kabupaten Bandung Barat," Jurnal Ilmiah Pekerjaan Sosial, vol. 15, no. 2 (Desember 2016) https://doi.org/10.31595/peksos.v15i2.87

Djawahir, Abdillah Ubaidi. "Asset Based Community Development di Pesantren Wisata: Implementasi Strategis di PP An-Nur 2 Al Murtadlo Malang," At-Tamkin: Jurnal Pengabdian Kepada Masyarakat, vol 1, no. 1 (Juni 2018). http://ejournal.uniramalang.ac.id/index.php/attamkin/article/view/95/44

Dureau, Christopher. Pembaru dan Kekuatan Lokal Untuk Pembangunan. Australian Community Development and Civil Society Strengthening Scheme Tahap II, 2013.

Faizal. "Dakwah Bil Hal Dalam Perspektif Al-Qur'an," Jurnal Ilmu dakwah dan Pengembangan Komunitas, vol. 8, no. 2 (Juli 2013).

Fedryansyah, Muhammad \& Risna Resnawaty. "Penanggulangan Kemiskinan Melalui Pengembangan Aset Komunitas," Social Work Journal, vol. 7, no. 1 (Juli 2017). https://doi.org/10.24198/share.v7i1.13828

Ife, Jim \& Frank Tesoriero. Community Development: Alternatif Pengembangan Masyarakat Di Era Globalisasi. Yogyakarta: Pustaka Pelajar, 2016.

Indonesia, Unilever. Buku Panduan Sistem Bank Sampah \& 10 Kisah Sukses. Jakarta: Unilever, 2014.

Kamus Besar Bahasa Indonesia, aplikasi, 5.1

Kriyantono, Rachmat. Teknik Praktis Riset Komunikasi: Disertai Contoh Praktis Riset Media, Public Relation, Advertising, Komunikasi Organisasi, Komunikasi Pemasaran. Jakarta: Kencana, 2010.

McKnight, John \& Cormac Russel. The Four Essential Elements of an Asset-Based Community Development Process. Asset-Based Community Development Institute, 2018.

Nasution, Ahmadriswan, "Peranan Modal Sosial dalam Pengurangan Kemiskinan Rumah Tangga di Pedesaan Indonesia," Jurnal Ekonomi \& Kebijakan Publik, vol. 7, no. 2 (Desember 2016). Doi: 10.22212/jekp.v7i2.672

Nawawi, Hadri \& M. Matini. Instrumen Penelitian Bidang Sosial. Yogyakata: Gajah Mada University Press, 1992.

Kamaluddin. "Dakwah dan Pengembangan Masyarakat Islam (Konsep Dasar dan Arah Pengembangan)," HIKMAH: Jurnal Dakwah dan Komunikasi Islam, vol. 8, no. 2 (Juli 2014): 41-52. http://repo.iain-padangsidimpuan.ac.id/256 
Undang-Undang Republik Indonesia Nomor 11 Tahun 2009 Tentang Kesejahteraan Sosial, Pasal 1. https://luk.staff.ugm.ac.id/atur/sehat/UU-11-2009KesejahteraanSosial.pdf Romlah, Siti. (Ketua Bank Sampah Songolikoer). Wawancara oleh Wahanani. Tanggal 11 Desember 2019.

Rudianto. (Ketua Kader Lingkungan Wonokusumo Kidul). Wawancara oleh Wahanani. Tanggal 12 Mei 2018.

Soeharto, Edi. Membangun Masyarakat Memberdayakan Rakyat (Kajian Strategis Pembangunan Kesejahteraan Sosial dan Pekerjaan Sosial). Bandung: Ikapi, 2014.

Theresia, Aprilia. Pembangunan Berbasis Masyarakat. Bandung: Alfabeta, 2015.

Winarto, Agus (Ketua RW 2018-2019, penggagas Bank Sampah Songolikoer, dan pembina kader lingkungan). Wawancara oleh Wahanani. Tanggal 17 April 2018. 
Wahanani Mawasti

Fasha Umh Rizky

54 | INTELEKSIA - Jurnal Pengembangan IImu Dakwah 